\title{
No Nastas'ias on the Volga: \\ Soviet Women Veterans and Folkloric Self-Representations
}

\author{
Adrienne Marie Harris \\ Baylor University \\ Waco, Texas, USA
}

\begin{abstract}
"No Nastas'ias on the Volga: Soviet Women Veterans and Folkloric Self-Representations" investigates how the Soviet women pilots of the $46^{\text {th }}$ Guards Regiment who served in World War II employed folkloric imagery to represent themselves in wartime poetry and in memoirs published between 1960 and 2002. The article argues that the women's employment of this imagery gives insight into how they constructed their collective identity, how they negotiated shifting expectations for gender, and how, in the twentieth century, they interpreted folkloric images they inherited from the past. The author's approach bridges disparate bodies of scholarship in the fields of folkloristics, gender studies, and history. The author analyzes the meanings of both the images which the pilots appropriated - the bogatyr' [the male knight], witch, and to a lesser extent, the eagle and swallow-as well as a key folkloric personage whom memoirists ignored: the polianitsa [woman knight]. In a broader context, this article elucidates how a marginalized, silenced cohort used its cultural heritage to create a unified identity, carve a place for itself in a larger collective memory, and how its utilization of cultural tools evolved with the passage of time.
\end{abstract}

Скажет Дунаюшка Иванович:

--Ай же ты, Настасья

королевична!

Поедем, Настасьюка, в чисто поле,

Стрелять стрелочки каленыя. И выехали во чисто поле:
Dunai Ivanovich then spoke: "Hail to you, Nastas'ia the Princess!

Let's ride, Nastas'ia, to the open field,

To shoot some tempered arrows.” And they rode out to the open 
И стреляла ёна стрелочку каленую,

И попадала стрелкой в ножечной острей,

Рассекала стрелочку на две половиночки,

Обе половинки ровны пришли, На взгляд ровнаки и весом ровны

И стрелил Дунаюшка Иванович;

Так раз стрелил, перестрелил, Другой раз стрелил, не дострелил, И третий раз стрелил, попасть не мог.

[Gil’ferding 1938: 168] field.

And she shot a tempered arrow

And with the arrow she hit the edge of a knife,

She cleaved the arrow into two halves, Both halves came out equal, Equal to the eye and even in weight.

And Dunai Ivanovich shot, He shot a first time and overshot, He shot a second time and undershot, He shot a third time and missed.

[Bailey and Ivanova 1998: 198] (1)

Images and stories of fighting women like the polianitsa [female knight] Nastas'ia pervade Russian folklore, literature, and history. Dating back to the pre-Christian period, they appear with increasing frequency in modern history. Well-known examples include Alena Arzamasskaia (Temnikovskaia) in Stenka Razin’s uprising, Nadezhda Durova during the Napoleonic wars, the women's death battalion in World War I, the fictional Anka Pulemechitsa and her countless historical counterparts in the Civil War, and most recently, the 800,000 women who fought in World War II, both on the front and in the resistance as partisans. (2) Like Nadezhda Durova, women World War II veterans wrote about themselves after their service (1960s-2000s), carefully crafting narratives that demonstrate their successes as soldiers and their equality and occasionally, their superiority to men on the battlefield. Many women veterans who employed folkloric imagery to represent themselves inserted themselves into epic narratives and into national mythology.

Surprisingly, the most unified and prolific writers, the veterans of the $46^{\text {th }}$ Guards Women's Aviation Regiment, 


\section{Women Veterans and Folkloric Self-Representations 101}

embraced both the seemingly contradictory images of the bogatyr' [the male knight] and ved'ma [the witch]. Meanwhile, they ignored the polianitsa, the female counterpart to the bogatyr'. In "Dunai," as well as in other byliny, she often out-performs bogatyri in traditionally masculine activities. A close reading of these women veterans' postwar autobiographical works (1968-2002) reveals that these authors wrote, in part, to correct misconceptions and to clarify misunderstandings about their capabilities and feats in World War II and their absolute equality or superiority to men in air combat. Why, then, did they ignore the image of the polianitsa while representing themselves using other folkloric personages? What do the women veterans' choices to appropriate certain folkloric images and to ignore others when representing themselves reveal about the complex relationships between folklore, identity, gender, and collective memory? What do these preferences tell us about both the historical situation in which these women wrote first personal narratives and certain folkloric personages in Russian culture? (3)

Natalie Kononenko has pointed out that "since folk belief affected all strata of Russian society, folklore helps us understand not only peasant women and their songs and tales, but also beliefs encountered by upper-class women who chose to write," [Kononenko 1994: 17]. In a broader context, Elaine Showalter has advocated the position that literature not only documents, but constructs human sexuality and gender identity [Showalter 1992: 15], leading one to ask how the identities that these veterans assumed, the role models they acknowledged, and those they ignored or rejected reflect wartime and postwar culture and collective memory. This article commences with a brief discussion of the historical situation and cultural context that prompted these veterans to pen self-referential texts; it examines women veterans' appropriation of folkloric terminology when depicting themselves and their comrades, both during the war in songs and poetry and after the war, in memoirs and film. The article subsequently analyzes two figures from the East Slavic epic tradition, the bogatyr' embraced by the pilots and the neglected polianitsa, before turning to a discussion of the witch. Since the pilots' witch

FOLKLORICA 2013, Vol. XVII 
identity originated as a Nazi insult, I discuss the witch in both the German and Slavic cultural contexts.

An analysis of these women's literary choices sheds light on both twentieth-century interpretations of folkloric images the memoirists inherited from the past and women veterans' selfrepresentations. I argue that when the pilots of the $46^{\text {th }}$ guards aviation regiment began referring to themselves as ved'my in the 1960s, rather than bogatyri, the term they had used during World War II, they transitioned from a general symbol embraced by aviators to a feminine identifier that was specific to their particular regiment. During the war, their choice of the masculine bogatyr' gives evidence that they wanted primarily to be treated as equals to men in combat, without drawing attention to their gender. When they began employing the feminine ved'ma in memoirs, they began promoting a more specific identity, juxtaposing themselves with the male veterans after the commencement of the state-sanctioned cult of World War II, as defined by Nina Tumarkin in The Living and the Dead and Lisa Kirshchenbaum in The Legacy of the Siege of Leningrad, 1941-1995. (4) During the roughly two decades that separated these pilots' utilization of the bogatyr' identity and the time when they identified as "night witches," gender and women's roles in the military were revised. In a broader context, this article elucidates how a marginalized, silenced cohort used its cultural heritage to create a unified identity and to carve a place for itself in a larger collective memory. It outlines how their utilization of their folkloric heritage evolves with the passage of time.

"Letat' $v$ nebe-razve eto zhenskoe delo?" ["Flying in the Sky-is that really a woman's business?”]: The Historical Context

Zuleikha Seidmamedova, (5) an Azerbaijani navigator, begins her 1969 Zapiski letchitsy with an epigraph that challenges the woman's place in aviation: “Летать в небе-разве это женское дело?” [“Flying in the Sky---is that really a woman's business?”] [Seidmamedova 1969: 5]. She, in turn, responds to the challenge by portraying herself and her comrades as skilled pilots and heroic fighters. Seidmamedova and the Soviet women 


\section{Women Veterans and Folkloric Self-Representations 103}

pilots who fought in World War II faced this challenge three times. In the late 1930s, encouraged by famous examples and images of armed women in the media, they flocked to air clubs and, in spite of discrimination, they fought for the right to fly. (6) They became pilots and flight instructors who maintained that women should be allowed to join the militarization movement, even if they were not allowed to attend state military academies. (7) After the Nazi invasion of the Soviet Union on 22 June 1941, these aviators demanded to serve at the front, only to be told that the war was not women's business and were sent home, or directed to nursing school as an alternative. After the famous aviator and Hero of the Soviet Union Marina Raskova received permission in October 1941 to form three women's aviation regiments, (8) the women recruits performed heroically as combat pilots, exceeding expectations, and proved definitively, they thought, that women had the right to wage war in the skies. However, after the war, upon their collective demobilization, the nation fell virtually silent about these women's heroic deeds.

In a 1945 speech, Mikhail Kalinin explicitly urged women to not be boastful of their feats and service [Kalinin 1953: 428]. Postwar state needs and policies resulted in representations of women soldiers that corresponded to strictly-defined gender roles. Reina Pennington notes that "even in fiction, there was an increasing tendency to minimize the role of the women participants in the postwar years" and Barbara Alpern Engel points out "gender stereotyping" and the postwar emphasis on pro-natalism [Pennington 2001: 155; Engel 1999: 149]. As a result, during the 1950s, women pilots, and women veterans in general, found themselves on the periphery of collective memory. (9) As the cult of World War II began to take shape in the 1960s [Tumarkin 1994], it became clear that armed women combatants and skilled aviators had been forgotten, rather than celebrated, as they had been during the pre-war mass militarization campaign of the 1930s. After fifteen years of silence, these women began fighting back, actively engaging in another battle: a battle for cultural heritage, for a place in the nation's cultural memory, and for the metaphorical resurrection of lost comrades in arms.

FOLKLORICA 2013, Vol. XVII 
In her in her discussion of autobiography, Shari Benstock argues that female autobiographers craft responses from the position of "The Other" [Benstock 1997: 1143]. Women pilots' memoirs indicate that as a whole they were and had always been aware of their marked otherness in relation to male pilots and that they wanted to be remembered by future generations precisely as women who confronted and challenged boundaries to become skilled aviators and defenders of their nation in its most dire hour. They believed that they had proved themselves in combat and in their memoirs, they attempted to push themselves out of the periphery, into a more central space in collective memory.

"Vpered, orly, vpered, bogatyri!" ["Forward, eagles, forward, knights!’]: War-time Self-Representations

Of the three women's regiments formed by Marina Raskova, the women of the $46^{\text {th }}$ Guards Night-Bomber Regiment, the only regiment of the three to remain solely female throughout the war, wrote most prolifically about their individual and collective experiences. Two specific veterans of this regiment dedicated many of their later years to penning memoirs and biographies of former comrades-in-arms: veterans' advocate Marina Chechneva and author of youth literature, Natalia (Meklin) Kravtsova. These collective-minded veterans authored more books about their comrades than about themselves. Not surprisingly, Chechneva chose Kravtsova's words, an excerpt from the regimental march composed in 1943, as the epigraph for her 1968 biography Letali devchata $v$ gvardeiskom [Girls flew in a Guards Regiment]. Her choice points to the representative function of this march in the regiment's collective identity during service as well as the women's memory of the war. The march captures how the women pictured themselves during the war, at the precise moment they were fighting the enemy:

На фронте стать в ряды передовые

Была для нас задача нелегка.
[To stand on the front in the advancing ranks Was not an easy task for us. 
Боритесь, девушки, подруги

боевые,

За славу женского гвардейского полка!

\section{Припев:}

Мы слово гвардия, прославленное слово,

На крыльях соколов отважных пронесем,

За землю русскую, за СТАЛИНА родного,

Вперед, за Родину, гвардейский женский полк!

Никто из нас усталости не знает, Мы бьем врага с заката до зари.

Гвардейцы-девушки в бою не подкачают

Вперед, орлы, вперед, богатыри!
Young women, girlfriends-inarms,

Fight for the glory of the

Women's Guards Regiment!

Refrain:

On the wings of courageous

falcons,

We will carry the word of the guard, the glorified word For the Russian land, for our native STALIN

Forward, for the Motherland, Women's Guards Regiment!

None of us know exhaustion, We beat the enemy from sundown to sunrise.

Guards-young women won't let you down in battle Forward, eagles, forward, (male) knights!]

[Chechneva 1968b: epigraph]

The march, written in celebration of the conference of the "guards" honorific in 1943, references the aviators' feminine gender explicitly four times, and in keeping with wartime cultural documents, describes their bravery and relentless aggression against the enemy and identifies their patriotic motivations to wage war. (10) While the march is specific to World War II and the Stalinist period, several key words root this twentieth-century march in the East Slavic folkloric tradition: the bird imagery and the aviators' concluding self-identification as bogatyri, the Russian knights of byliny, epic poems, most of which were originally composed between the tenth and fourteenth centuries [Bailey 1998: xvii]. In their memoirs, the pilots of the $46^{\text {th }}$ frequently note with pride that their regiment acquired the distinction of being a guards unit; this distinction remained one of the unifying sources of pride for these pilots. As such, it served a key role in the regiments' 
collective identity. Through the performance of Kravtsova's march, the women pilots collectively celebrated their aviator identities and challenged gender norms by referring to themselves as bogatyri long after demobilization and the implementation of policies that prohibited women from combat had pushed them into the domestic sphere [Pennington 1996: 143].

The tendency of Soviet women soldiers to represent themselves and their comrades-in-arms by employing terms and motifs appropriated from Russian folklore is hardly surprising within the context of wartime culture. Frank Miller has referred to the years between 1937 and 1941 as a "renaissance for Russian folkloristics" and during the period just prior to the war, numerous exhaustive anthologies of folklore saw light. [Miller 1990: 10]. Pilot Raisa Aronova explicitly places pilots within the culture of heroism in her memoir Nochnye ved'my [Night Witches] when she remembers how in the 1930s she conceived of aviators as some type of magical-bogatyri [Aronova 1969: 7-8]. The very nature of aviation led to the application of metaphoric avian references, previously reserved for bogatyri and heroes in folk tales, to pilots. The Soviet press incorporated these references into headlines, strengthening the connection between the folklorist past and the Stalinist militarization campaign, contributing to the glorification of early Soviet aviators. This continued after the outbreak of war, when poster artists Iraklii Toidze and Mikhail Mel'tsev superimposed images of contemporary Red Army soldiers on backgrounds depicting bogatyri [Snopkov 2005: 119, 121], reinforcing the relationship between the past and Russia's latest battle in the epic struggle against foreign invaders.

In keeping with propagandistic depictions of Red Army soldiers as heroes from the epic past, the women of the $46^{\text {th }}$ guards regiment also chose to represent themselves as "bogatyri" or male knights, emphasizing their communality with pilots and demonstrating that women could be defenders of their homeland, regardless of gender. (11) This wartime appropriation of the bogatyr' self-image demonstrates on a grass-roots level the renewed relevance of folklore during the Stalinist period, which Laura Olson has argued was promoted in order to cultivate 
patriotism [Olson 2004: 39]. Although Red Army soldiers who served in various capacities were cast as bogatyri because of their roles as defenders of the Motherland, the figure of the bogatyr' best symbolized the pilot. The pilot/plane serves as a logical analogy to the knight/horse pair. In prewar propaganda, journalists christened pilots "Stalinskie sokoly" [Stalin's falcons], as the falcon was both a widely recognizable symbol for the bogatyr' [Bailey and Ivanova 1998: 8, 62] and a universal symbol for the aviator. Of the women memoirists, Chechneva and Kravtsova, the two most prolific veteran-authors and conservators of the memory of women pilots, were the most attracted to images from the byliny. In Letali devchata $v$ gvardeiskom, Chechneva cites a wartime poem written by a fallen comrade-in-arms, Evgeniia Rudneva. In this poem, Rudneva also employs the image of the grammatically-masculine eagle, always a male character in Russian folklore:

\author{
Мы будем драться, как орлы, не уступая, \\ Как соколы, крылаты и тверды́. \\ [We will fight, like eagles, not giving in, \\ Like falcons, winged and resolute.] [Chechneva 1968b: 51]
}

Here Rudneva and, through her citation, Chechneva ignore traditional gender paradigms in the lexicon inherited from the folk tradition by employing images of aggressive male, birds of prey to represent her comrades, rather than birds typically associated with women. Since the eagle is traditionally a symbol of bravery, strength and invincibility [Ivanova-Kazas 2006: 15] and the falcon, a universal symbol of the aviator, Rudneva and (Meklin) Kravtsova, in her march, represented themselves and their fellow pilots with those birds during the war regardless of their comrades' gender. During the war, urgency prevented the Soviet citizens from questioning the "naturalness" and femininity of women soldiers as they would in the postwar period. As the female pilots initially embraced their identities as bogatyri, they assumed the bogatyr's symbol: the falcon. 
In the Russian tradition, the grammatically-feminine lastochka [swallow] serves as a symbol of kindness, happiness, peace, family contentment, and otherworldliness [Ivanova-Kazas 2006: 102-103]. These traits contrast dramatically with those associated with grammatically-masculine birds of prey. In light of the traits of the swallow, the title of Chechneva's 1984 memoir "Lastochki" nad frontom [Swallows over the Front], signifies a noteworthy shift in cultural expectations for men and women. The title underscores traditionally feminine traits before the reader ever read about the women's wartime contribution; it sends a message of domestication and may point to a surprising incongruity between swallows and the front. (12) The choice conforms to postwar expectations for women, as evidenced in Larisa Shepitko's 1966 film Kryl'ia [Wings]. Immediately after the war, the Soviet Union saw what Reina Pennington has described as a "retrenchment" in gender attitudes and societal structures [Pennington 1996: 141].

In addition to the negotiation of gender through folkloric imagery, the pilots' re-situation of themselves and their comradesin-arms within a folkloric context seemingly accomplished a significant objective in the crafting of the nation's historical narrative: by representing themselves as specifically bogatyri, the pilots represent themselves as part of an epic, a narrative that deals with a heroic figure or figures and a historical event, such as a war or some other achievement central to the establishment of traditions, the identity of an ethnic group or a nation and its cultural values [Preminger and Brogan, eds. 1993: 361]. Through their self-representation as part of an ancient tradition of fighters defending the nation, the memoirists connect themselves to the deep past. In their Guards' oath, the poetic voice situates even the enemy within the discourse of folklore, pledging to shoot the "fashistskikh razboinikov" [the fascist robbers/brigards]; certain folkloric genres, including the byliny, feature razboiniki as enemies. By casting the enemy as a razboinik, the detested villain in the bylina "Il'ia Muromets and the Nightingale-Robber," the women veterans incorporate themselves into a centuries-old narrative in which brave knights defend the motherland from 


\section{Women Veterans and Folkloric Self-Representations 109}

invaders in a larger, national struggle. Through the collective, wartime performance of Kravtsova's march, the pilots were already contextualizing themselves in epic time, preparing for the future in which their service would be part of their nation's past. Mikhail Bakhtin has claimed that the epic narrator speaks about a past which is inaccessible to him or her, in which the "represented world of the heroes stands in an utterly different inaccessible timeand -value plane, separated by epic distance” from the singer and listener [Bakhtin 1981: 13-14]. This inaccessible distance would become increasingly powerful as the years passed and the women pilots realized that in addition to being demobilized from the military, women pilots and other combatants had been largely forgotten in the nation's collective memory and marginalized in a postwar culture that responded suspiciously to women combatants [Alexiyevich 1988: 189-191]. The incorporation of texts referencing the bogatyri into memoirs published during the sixties, seventies, and eighties gives evidence that the women veteranmemoirists were writing, in part, to challenge the dominant versions of history that ignored their contributions and focused instead, as Anna Krylova points out, on the victimization of women who fought in the war [Krylova 2010b : 87-91].

"Vpered, bogartyri"...a ne polianitsy? ["Forward, male knights”...but not female knights?]

While the female pilots' employment of a figure from epic poetry complements the objectives of writing oneself into the narrative of World War II and highlighting one's role in a national struggle, why would they choose to represent themselves as male bogatyri, rather than the female polianitsy? Adele Marie Barker has noted that the byliny are composed largely around the theme of mother-son relationships; thus, she argues that a psychological plot in which the ego frees itself from the mother figure is embedded within stories of bogatyri who fight foreign enemies or set out on quests [Barker 1986: 24]. Yet, in spite of Barker's findings, the women pilots' utilization of the bogatyr' figure to represent themselves does not fit into this paradigm, especially as the women 
pilots never denied their femininity but stressed it in their memoirs. By professing a love for traditionally feminine interests such as flowers and needlework, the memoirists clearly specify that they did not want to be men, in spite of their identity as soldiers.

While the veterans combined traditionally feminine qualities with warrior traits, constructing what Anna Krylova has described as non-oppositional, yet still binary gender identity [Krylova 2010a: 13-14], the women veterans represent themselves so that, like the polianitsy, they appeared every bit as skilled in warfare as their male peers, if not more. In fact, the women veterans of the $46^{\text {th }}$ sometimes argued that their gender made them better pilots, as they would not drink or smoke before flying, or because of their strength of will [Aronova 1969: 193-194]. Members of the other women's regiments agreed: dive bomber Evgeniia Guruleva-Smirnova, a dive bomber claims, "We had fewer casualties in our regiment than the men did flying the same type of aircraft; I think we were more exact in our flying” [Noggle 1994: 111]. They understood their role in history and the need to prove their prowess. They kept diaries during the war, as if they were conscious of the fact that they were changing history and needed to document it [Krylova 2010a: 12-13]. Marina Chechneva worked to the end of her life to prove that women were equal to men in aviation, both in civil service and through the publication of numerous books about her comrades-in-arms and herself [Volkov 1972: 40].

The pilots' memoirs show that they were familiar with other women fighters: Nadezhda Durova, Anka Pulemechitsa, Marina Raskova, Zoia Kosmodemianskaia. Anna Krylova argues that they aimed to "redraw gendered identities of combat by proving women's ability at modern war” [Krylova 2010a, 12]. With their familiarity with cultural and historical precedents, and with the demonstrated objective of representing themselves as fighters equal to men on the battlefield, yet very much not men, their complete absence of identification with the polianitsa, the woman knight, even in the postwar period when they were reflecting on their self-images in order to craft narratives, points to a potential unsuitability of the polianitsa. In her discussion of 


\section{Women Veterans and Folkloric Self-Representations 111}

Greek female warriors, Elizabeth Constantinides advances the position that "Jungian analytical psychology might consider the warrior maiden as a manifestation of one of the great archetypes of the unconscious, the image of the other sex, in this case the animus or male element of the female psyche” [Constantinides 1983: 71]. The example of Nastas'ia cited in the introduction gives Russian evidence of such an archetype, but as Johanna Hubbs notes, earlier examples of polianitsy are more aggressive than later ones [Hubbs 1988: 149]. This trend seems to indicate that for whatever reason, Russians suppressed the polianitsy and the woman warrior archetype, even though they embraced strong women in other contexts. Why are polianitsy absent in these women's memoirs?

The women pilots might not have known about the polianitsa, but considering their educational levels and cultural knowledge, this gap in knowledge seems unlikely. The Russian Academy of Science published numerous collections of byliny during the 1930s and 1950s. Although curriculum varied from school to school, byliny, related themes and related characters were taught in some Soviet schools. (13) The nationality of the polianitsy might provide another clue: polianitsy were always foreign, neither Russian nor Orthodox. Their foreignness might have precluded the pilots-memoirists from identifying with them: in memoirs, consistent with the war cult and women's explanations for their fighting, the women pilots claimed to fight primarily out of patriotic love for their country. In the byliny, the male bogatyri, rather than the female polianitsy, defended the Russian land from invaders and infidels.

A close reading of the byliny points to another potential explanation of why the veterans ignored the polianitsy: they may not have appreciated the conclusions of the byliny-what happens after the polianitsa marries the knight. As Kononenko has pointed out, the byliny are peppered with tragic elements and the death of a hero's wife, a polianitsa in many cases, occurs nearly as frequently as the death of the hero [Kononenko 1994: 19]. The bylina was the one East Slavic folk genre performed exclusively by men prior to the twentieth century [Kononenko 1994: 18]. Kononenko argues that "Russian epics also express the hope that marriage will subdue 
a woman" and cites an example in which the polianitsa Nastas'ia becomes a perfect wife after marriage to Dobrynia. As a single woman, the polianitsa had been monumental in size, yet after marriage, she shrinks to an average size [Kononenko 1994, 26]. The message is clear: matrimony tames this bold, brave creature and transforms her into an ordinary and non-threatening woman. According to Kononenko, Natas'ia's transformation seems like the fulfillment of male wishes, rather than female desires. In the twentieth-century context, Soviet pro-natalist policies and a postwar cultural bias against women soldiers disarmed the veterans; (14) they were expected to marry and help rebuild the population, and most did. Perhaps they resented the character's discouraging fate in the byliny which represented a male point of view and because they had no intentions of masquerading or passing as men after demobilization, they could not identify with the polianitsa.

A comparison of the folkloric imagery in postwar texts with the imagery composed during the war points to an evolution of the authors' gender identity, complicating Krylova's assertion that the pilots constructed a "non-oppositional binary." During the war, the pilots attempted to prove equality to men and chose traditionally male images. By ignoring the polianitsa and embracing the bogatyr', they identified with a masculine, unmarked, universal image, just as they chose to represent themselves using grammatically-masculine birds during the war. In the postwar period, while they were trying to reclaim a place in the nation's collective memory, their balance of traditionally feminine and soldierly traits shifted and they employed more traditional feminine images: the switch from the eagle to the swallow in the title of Chechneva's "Lastochki" nad frontom [Swallows over the Front] in 1984, accompanies the abandonment of the bogatyr' for a more traditionally-feminine, albeit marginal and marked, folkloric personage. The folkloric imagery shows a dynamism in the pilots' gender identity for which Krylova does not account. 
"Tochno exo dalekoi pesni" ["Precisely the Echo of a Distant Song]: The Epic Past in Postwar Poetry

After the war, pilot veterans composed no new texts in which they identified themselves as bogatyri, even if they did cite Kravtsova's march, perhaps because of the historical situation: the women stopped trying to prove themselves equal to men in combat. After the war, they transformed themselves from uniformed soldiers into civilian veterans. As veterans penning their own narratives, they focused on their superiority in war, rather than their equality, and the image of the powerful witch eclipsed that of the bogatyr'. One might argue that the women's postwar lack of engagement with the image of the bogatyr' corresponds to the cultural context: after the war, the organs of propaganda stopped representing Red Army soldiers as bogatyrithere was no need. But a brief foray into the poetry of Iuliia Drunina shows that into the 1970s some women veterans represented themselves as fighters in the epic history of their nation.

Since the war, Iuliia Drunina's work has been frequently published, read, and cited. She remains by far the most wellknown World War II woman veteran writer. While Drunina served in a radically different capacity from the pilots because she was a medic, and was not part of a cohort of women, the women pilots themselves use her words to convey their experiences: Galina Markova even referenced one of Drunina's poems in the title of her memoir Iunost' v ogne [Youth on Fire]. (15)

In her poem "Drunia", written in 1972, contemporaneous with the deluge of pilot-penned memoirs, poet Iuliia Drunina reflects upon her military experience, linking herself to Russia's military past and identifying herself as a warrior amongst warriors. Through her name "Drunina" and her diminutive form "Drunia," she connects herself to the folkloric druzhína [retinue], the retinues of bogatyri in byliny. (16) She describes her experience in a metaphorical druzhina, using the word "kol'chuga" [chain mail or armor] to transport the reader into the distant medieval past:

FOLKLORICA 2013, Vol. XVII 
Пахло гарью в ночах июня,

Кровь и слезы несла река, И смешливо и нежно «Друня» Звали парни сестру полка.

Точно эхо далекой песни,

Как видения, словно сны,

В этом прозвище вновь воскресли

Вдруг предания старины.

В этом прозвище-звон кольчуги,

В этом прозвище-храп коня,

В этом прозвище слышно:

--Други!

Я вас вынесу из огня!

[Drunina 1989: I-406-7]
[It reeked of burning in the June nights.

The river bore blood and tears, And amusingly and sweetly, The young men called the regimental nurse "Drunia." Precisely the echo of a distant song

Like of a vision, or as if of a dream, The legends of antiquity Suddenly resurrected anew in this nickname.

In this nickname, there's a clank of chainmail

In this nickname, a horse's snort.

In this nickname, one hears

'Friends!

I'll carry you out under enemy fire!']

Against the background of the medieval past, she foregrounds the camaraderie she shared with her brothers-in-arms during World War II. She identifies herself as a sister among brothers, and her role as a nurse does not diminish her status among the other warriors. She protects her brothers, saves them by carrying them from danger and even sees her role as Russia's protector imbedded in her name. In fact, her name resurrects the byliny and casts her military service in WWII as merely the most recent of such episodes in Russia’s history.

The Drunina example shows that some women did not stop envisioning themselves as warriors, but specifically these women, the pilots of the $46^{\text {th }}$ Guards, did, and chose instead to represent themselves with another folkloric image, an image specific to their 


\section{Women Veterans and Folkloric Self-Representations 115}

regimental identity. As time went on, women veterans increasingly emphasized their identity as "night witches."

"Nas nazvali nochnymi ved'mami" ["They Called us Night Witches”]

The only film directed by a woman veteran pilot and at least two memoirs reference the term "night witches" in titles and thus, the figure acts as the introductory image that draws the viewer and reader into collective narratives. The Germans initially started calling the women pilots "night witches" early in the war, after discovering that the pilots who had been gliding in on stealth missions were not men, but women. Recent interdisciplinary research on witchcraft has confirmed that the image of the witch varies greatly from culture to culture, dependent upon social contexts, ideologies, and belief systems [Klaniczay and Pocs 2008: 1]. In light of these facts, what did the Nazi soldiers' insult "witch" convey within the context of German culture? As in Russian, German beliefs about witches stretch back into the deep Indo-European past. However, through the passage of centuries, the nations' folkloric beliefs about witches and witchcraft developed into distinct traditions. Sigrid Brauner has shown that the German image of the witch underwent a transformation in the fifteenth and sixteenth centuries as humanist and Protestant thinkers reinterpreted women's roles in the family and in society [Brauner 1995]. Prior to the late 1400s, men were as likely as women to be accused of witchcraft, but by 1500, the sexspecificity of witches as female was so widely accepted that it was assumed in texts [Brauner 1995: 13-15]. Brauner outlines the characteristics of the witch in the modern folk imagination: she is female, uses magic to harm others, attends secret "Sabbath meetings," flies through the air at night, and seals a pact with the devil by copulating with him [Brauner 1995: 7].

The Germans' nickname for the pilots, "Nachthexen," references the witches' inherent destructive nature, in this case, the tremendous damage caused by the women when they dropped their bombs during the night, silently, as if through supernatural means, 
and caused tremendous destruction. Journalist Svetlana Alexiyevich reports that the Nazi press further vilified these women and alluded to their "unnaturalness" by claiming that these women pilots were "female bandits released from prison" [Alexiyevich 1988: 153], pointing to the danger these pilots represented. Furthermore, like witches in the German tradition, these women subverted traditional gender roles. Johannes Nider, the author of the 1435 treatise on witches, Formicarious, stresses women's powers of deception in their transgression of gendered norms, which reverses the divine order [Brauner 1995: 39]. Many of those who wrote about witches, such as Heinrich Kramer and Jakob Sprenger, the authors of the definitive Malleus maleficarum [The Hammer of Witchcraft] (1487), attributed lust to witches, among other negative emotions [Brauner 1995: 61]. Women witches are sexually depraved in the German tradition, so that labeling a woman with such a name insults her very existence. In the German conceptualization, the Nachthexen were not pilots or fighters; by virtue of their female sex, they were much more base creatures. The participation of these Soviet women pilots in combat directly contradicted the woman's maternal role in Nazi culture.

The Russians appropriated Nachthexen and translated the insult as nochnye ved'my. What, then, does the witch, specifically the ved'ma, mean in the Russian context and why did Russian women proudly re-appropriate this insult and use it to represent themselves? In the Russian context, the ved'ma differed from the modern witch in the German context, sharing much more with premodern notions of sorceresses and sorcerers. The root of the word ved'ma connotes “knowing” or "knowledge." Practitioners of magic, both male and female, are known in Russian from the earliest of records [Ryan 1999: 78-79]. While members of both genders could practice sorcery, this particular term was gendered as feminine. (17) As in German folklore, the witches of Russian legends were believed to be capable of flight and were seen as primarily negative characters who associated with dark forces and cursed, spoiled, and gave the evil eye. One could be born a witch or acquire powers, either through active cooperation with the devil 
or through transference of power from a dying witch, although Ivanits has noted that the vast majority of instances of witchcraft mentioned in Kievan and Muscovite documents do not mention the devil [Ivanits 1989: 93]. Beliefs in witchcraft and witches were deeply ingrained in the popular imagination [Ivanits 1989: 84-85]. Although memoirists were highly educated, they were almost all only one generation removed from the countryside and the world view of older relatives would have certainly shaped their conceptions of witches and witchcraft.

In her 1969 memoir Nochnye ved'my [Night witches], Raisa Aronova presents the insult as part of a gendered binary, rooted in folklore, relayed by the male division commissar Borbunov to Evdokiia Bershanskaia, the commander of the $46^{\text {th }}$ guards regiment. After noting the women pilots' habits of sleeping in their cabins so that they would be ready for combat at a moment's notice, he began complimenting Bershanskaia on the regiment's early successes, flying in the first ranks of the division after only three months and being written up in the news. He states that the most significant or telling success is the fact that the enemy both knows and hates them. A captured German had described how the night bombers had brought misery to the Germans, not allowing them to sleep and both exhausting them physically and lowering their morale. The Nazis claimed that "the night witches" must have been responsible for the recent destruction of a bathhouse. The commissar continues, "So that means that only for me are you sleeping beauties, but for the enemy, you've turned out to be witches!" [Aronova 1969: 46]. In the second half of her narrative, a travelogue, Aronova describes her own experiences together with her former comrade-in-arms Rufina Gasheva's and husband Leonid Pliats's as they retrace the women's wartime route. After listing the talents of individual pilots, Aronova reflects on the regiment's collective identity and at one point struggles to describe her comrades:

--«Житие»--у святых,--а мы...

--«Ночные ведьмы», ввернул муж.

Руфа покосилась на него:

FOLKLORICA 2013, Vol. XVII 
--Мы не были ведьмами, конечно...

--Но и не ангелы!-поддразнивает Леша.

["Saints have "saints' lives, but we..."

“Are night witches!”-interjected her husband.

Rufa looked askance at him:

"We were not witches, of course..."

“But you weren’t angels, either! --teased Lesha]

[Aronova 1969, 246].

By relaying this conversation, Aronova again reproduces a binary that places the women in an ambiguous position. In both instances, male speakers insist on contrasting the witches with unquestionably "good" figures. In her own memoir, Aronova, thus captures the complexity of the "night witch" identity in the context of both folklore and the war.

Evgeniia Zhigulenko portrays the multiplicity of the women pilots while highlighting their destructive power in $V$ nebe nochnye ved'my [Night Witches in the Sky], the one film about these women pilots to be directed by a woman pilot veteran. (18) Evgeniia Zhigulenko's 1981 film begins with a shot of a PO-2 plane bombing German tanks at night and showcases the pilots' appropriation of their "night witch" identity. The solitary plane wrecks havoc on the Germans below, destroying tanks as search lights seek the plane in vain. The Germans on the ground proclaim “Nachthexen! Nachthexen!" The little plane flies off, and the viewer then sees that a woman commands the plane just before the film's title appears. Through this introduction, the film conveys the destruction that the women brought upon the enemy and demonstrates their skills in battle. In the next scene, an exhausted commander and commissar provide details for the viewer: the night of the featured bombing marks the one year anniversary of their time on the front, the longest and scariest year of their lives. During the course of the film, the director addresses themes common in women pilots' memoirs and, through the introduction of a child adopted by the regiment, addresses Russian misconceptions about the "naturalness" of the pilots as "real" women: one character makes plans to bring up a child informally 
adopted by the regiment while another character carries on a chaste romance with a male pilot. Shortly after the women successfully bomb a German train, the narrator proudly notes the women's thousands of sorties and elaborates upon the meaning of the Germans' insult: such an insult means that the women fly well and harm the enemy. The film conclusion parallels the introductory scene: a biplane flies off over enemy territory, sending the message that the "night witches" will continue to wage war on the enemy intruders indefinitely.

In their discussion of collective identity and selfrepresentation, psychologists Marilynn Brewer and Wendi Gardner point out that "when collective identities are salient, in-group-outgroup categorizations become the most important basis for evaluating others." [Brewer 1996: 91]. The "night witch” identity conveys a special exclusivity-specific to the women of the $46^{\text {th }}$ Guards regiment and sets them apart from all of the other bogatyri who defended their nation in World War II: soldiers, pilots, even other women pilots. The most recent biography published incorporates the term into the title: Nas nazyvali nochnymi ved'mami [They called us night witches], showing that the women's identification with the term persists into the post-Soviet period.

The increasing identification with the witch marks a cultural turn in the memory of the war that corresponds to shifting attitudes relating to traditionally defined notions of femininity. Sergeant Klara Semenovna Tikhonovch, an anti-aircraft gunner describes her evolving gender identity in Svetlana Alexyevich's collection of interviews, War's Unwomanly Face: "Did those of us at the front want to be like men? At first we did, very much so; we cut our hair short and even changed the way we walked. But later?-hell, no! Later we so much wanted to dye our hair, we didn't eat sugar, but kept it to starch our fringes” [Alexyevich 1988: 156]. Private Klara Vailevna Goncharova, another antiaircraft gunner expresses similar sentiments: "Before the war I loved everything military and wrote to flying school to find out how to be accepted. Military uniform suited me and I loved discipline, order, the curt words of command. [...] But after the 
war I no longer wanted to follow any military calling. Somehow I couldn't. I wanted to take everything khaki-coloured off as soon as I could and put on something ordinary and feminine. I still have a feeling of revulsion towards trousers" [Alexyevich 1988: 157]. When the march was written, in 1943, the women were very interested in proving themselves equal to men and delighted when they learned that others had been surprised or confused by their gender. By the time they wrote their memoirs, women soldiers had been officially and culturally silenced. Widespread rumors questioning their sexual, morality, and naturalness as women had led numerous veterans to go to great lengths to prove their womanliness. For a variety of reasons, they stopped wanting to be mistaken for men and began representing themselves through a powerful female image, one existing on the edges of society, set apart by occult knowledge. In terms of archetypes, they chose the crone over the woman warrior. While the warrior is typically a masculine figure, the crone is both an undeniably feminine figure and a rebellious, potentially dangerous, and strong one.

Ultimately, these women identified with a legendary rather than epic personage. In the last book published by the women of the $46^{\text {th }}$ Guards' Regiment, the authors solidified a collective "night witch" identity. Two narratives by two individual authors-Rakobol'skaia's Drugogo takogo polka ne bylo [There has never been such another unit] and Kravtsova's (Meklin's) Tri goda pod zenimnym ognem [Three Years above Anti-Aircraft Fire]-comprise this book, Nas nazyvali nochnymi ved'mami [They called us Night Witches], published in 2002. The title "They called us night witches" references the past, the collective identity, and the collective nature of the regiment. Even the picture conveys this message: a modest PO-2 (U-2) biplane flies above a black and white photograph depicting ten pilots, in skirts, marching forward in unison. Rakobol'skaia locates her text in a mythological space by alluding to the pilots' legendary nature before she begins narrating their stories. She cites a poem written by (Meklin) Kravtsova: 
Пусть это тихие и скромные У2

Не из металла грудь и не из стали крылья,

Но сложатся легенды, и в словах

Переплетется сказочное с былью...
Just as the quiet and modest U-2 planes, Their chests made not from metal nor wings from steel, will make legends, so in our words, let that which is magical Interweave with the facts.

--Н. Меклин.

Outside of the title, Rakobol'skaia's narrative ignores the "night witch" identity until a telling passage on the last page, when she includes a song about fallen pilots written by renowned poet Evgenii Evtushenko, which was featured in Zhigulenko's film. Immediately after crediting the song to Evtushenko and noting that it was featured in Zhigulenko's film, she begins her concluding paragraph with the affirmation, "Yes, I know, that a woman can do anything!'[Rakobol'skaia 2002: 140] and a plea for peace so that their children and grandchildren would not see their friends burn in planes and tanks. She concludes by stating that in order to have peace, one must never forget what has happened in the past. The book, compiled long after the war, appeared after the silence that followed demobilization, the deluge of memoirs during the war cult, and the years of silence that followed after the fall of the Soviet Union. Clues throughout the text give evidence that the narrator's and compilers intended that the "night witches" be viewed not only as historical, but also as legendary. The women pilots always intended that the memory of their service and of their feats in battle would outlast them and be remembered for forever. Upon the realization that they had been excluded from the Soviet collective memory of the war, they took matters into their own hands and narrated their war stories in such a manner that they would become timeless, rivaling other narratives associated with this particular epic event in Russian history. 
Conclusion

Lisa Kirschenbaum has noted that "the negotiations involved in melding personal and official memory are particularly pronounced where the gendered dimensions of memory are at stake" [Kirschenbaum 2000: 552]. Men and women pilots construct narratives about their wartime service in radically different ways. While both genders describe missions and planes, the women of the $46^{\text {th }}$ Guards Regiment were much more likely to interweave cultural references, literature, and myth into their narratives in an attempt to situate their experiences into a larger narrative. Their brief forays into the realm of myth might be attributed to their otherness: as pilots, then soldiers, and finally veterans. Their incorporation of certain folkloric figures into their memoirs points to an evolution in their collective identity as women fighters and in their specific group identity as the $46^{\text {th }}$ Guards Regiment. Chechneva, Kravtsova, Aronova and Rakobol'skaia tell stories of veterans living on the margins of the Soviet collective memory of the war. Their voices, belonging to woman soldiers and then veterans, filled what Suanne Conze and Beate Fieseler have called "a blind spot in the history of the war" [Conze and Fieseler 2000: 209-234]. The appropriation of folkloric terminology in their first-person narratives illuminates the cultural and historical specificity of their experiences, both wartime and postwar; this approach is applicable far beyond the Russian context.

In these veterans' self-representative works, we see an evolution from folkloric images drawn from the propagandistic militarization campaign to a radically different type of mythological figure. Initially, while endeavoring to prove their equality on the battlefield, these women, like polianitsy, donned uniforms and demanded to be treated as the peers of their brothersin-arms. Their appropriation of the witch identity points to both a resolution of tension between traditional femininity promoted during the postwar period and the women's pride in their role as destroyers of the enemy. As "night witches," they carved out a special, unique place in the Soviet collective memory of World 
War II. On the other hand, the women's rejection of the polianitsa in all of the reflective first-person narratives points to a fundamental conflict of essentialist archetypes and constructedness of gender roles. Nastas'ia and the other polianitsy, while representing an ancient archetype, disconcertingly challenged gender roles and waged war only until they were forced to tame themselves upon marriage. As "night-witches," the women of the $46^{\text {th }}$ Guards Regiment continued to reassert their regimental identity as destructive, powerful, female pilots who had defended their homeland. Thus, there was no room for Nastas'ia - not on the Volga, where the women pilots learned to wage war in 1942, nor in their memoirs.

\section{NOTES}

1 All translations are the author's, unless noted, as in this case. This passage is taken from the bylina [East Slavic, medieval, epic, folk poem], "Dunai," which collector A. F. Gilferding recorded in 1871 in the Olonets province from the singer K. I. Romanov [Bailey 1998, 198].

2 See Adrienne Marie Harris (2008) Phd Dissertation The Myth of the Woman Warrior and World War II in Soviet Culture, The University of Kansas: Introduction; Natalia Pushkareva, (1997), Women in Russian History, trans. and ed. Eve Levin (Armonk: M. E. Sharpe), 82-83 for information on Temnikovskaia; Nadezhda Durova (1997) The Cavalry Maiden: Journals of a Russian Officer in the Napoleonic Wars. Trans. and ed. Mary Fleming Zirin: Introduction; Laurie Stoff (2006) They Fought for the Motherland: Russia's Woman Soldiers in World War I and the Civil War. Lawrence: University Press of Kansas; Anna Krylova's (2010) Soviet Women in Combat, cited in the bibliography.

3 For comparison's sake, one may wish to look to memoirs penned by male pilots. See Igor Kaberov's (1983) V pritselesvastika: Vospominaniia letchika-istrebitelia; Evgeniy Mariinskiy's (2006) Red Star Airacobra: Memoirs of a Soviet Fighter Ace 1941-45, edited by Artem Drabkin, translated by 
Vladimir Krupnik; Vasily B. Emelianenko’s (2005) Red Star Against the Swastika, edited by Sergei Anisimov and translated by Elena Markus; Vasiliy Restnikov's (2008) Bomber Pilot on the Eastern Front: 307 Missions Behind Enemy Lines, translated by Vladimir Kroupnik and John Armstrong, edited by Serguey Anisimov.

4 Nina Tumarkin, The Living and the Dead: The Rise and Fall of the Cult of World War II in Russia (New York: Basic Books, 1994) and Lisa A. Kirschenbaum, The Legacy of the Siege of Leningrad, 1941-1995: Myths, Memories, and Monuments (Cambridge: Cambridge University Press, 2006), 12-3. Although one might claim that the cult of the war officially began in 1965, when Victory Day was made a state holiday, but already in 1960, the Piskarevskoe cemetery was dedicated. The early 1960s saw the publication of books related to the war in a wide variety of genres: memoirs, elite literature (Konstantin Simonov began writing The Living and the Dead in 1959 and Vasil' Bykov began publishing in 1961), and even in propagandistic literature intended for youth (e.g., Viacheslav Kovalevskii 's 1960 Brat i sestra about Zoia and Aleksandr Kosmodemianskie).

5 Seidmamedova served in the $586^{\text {th }}$ Fighter Aviation Regiment-not the $46^{\text {th }}$ Guards night-bomber unit. While my discussion of folkloric imagery does not relate to the $586^{\text {th }}$ unit, Seidmamedova's epigraph and challenges apply to the vast majority of women who flew in combat during World War II.

6 See Reina Pennington, Wings, Women, \& War: Soviet Airwomen in World War II Combat Lawrence, KS: University Press of Kansas, 2010 and Anna Krylova, Soviet Women in Combat Cambridge: Cambridge University, 2010 for background on the 1930s militarization movement and the cohort of women pilots who fought in World War II.

7 As David Stone explains in Hammer and Rifle: The Militarization of the Soviet Union, 1926-1933, the mobilization of Soviet citizens as part of the militarization campaign began in July 1926 after Commissar for Military Affairs Kliment Voroshilov and Chief of Staff Mikhail Tukhachevskii began pressing for a stronger, better funded Soviet army, one that was prepared for war 
[Stone 2000, 21-22]. Propagandistic images and slogans urged Soviet men and women to master military technology and arm themselves. Civil defense organizations and the Komsomol promoted study in marksmanship and aviation. The Russian word for the process of "militarization" is "voenizatsiia."

8 These three units included: the $46^{\text {th }}$ Guards night-bomber regiment (originally the $588^{\text {th }}$ ), the $586^{\text {th }}$ fighter regiment, in which Seidmamedova served, and the $587^{\text {th }}$ (later $125^{\text {th }}$ Guards) bomber aviation regiment.

9 See Iuliia Drunina's poem "Dva vechera" ["Two Evenings"] in which Drunina captures some of the frustration women veterans felt less than a decade after the war when they realized that their wartime contributions had been largely forgotten in the collective memory of World War II and how repressed the idea of a woman soldier had become in Soviet society [Drunina, 1989: 141, 142].

10 For a discussion of wartime cultural documents, propaganda, and rhetoric, see Richard Stites, ed., Culture and Entertainment in Wartime Russia. (Bloomington, IN: Indiana University Press, 1995).

11 During the war, male pilots, too, appropriated avian imagery and responded to the propagandists' strategy of representing Nazi Germany as a dragon to be slayed [Kaberov 1999, 21, 120-121].

12 Unfortunately, Chechneva died suddenly in 1984, and this memoir was published posthumously, so that although I found no evidence in Chechneva's file held by RGASPI (The Russian State Archive of Socio-Political History), it is possible that a publisher or editor rather than a woman aviator chose this unlikely image.

13 For instance, Zoia Kosmodem'ianskaia wrote a paper on Il'ia Muromets.

14 Reina Pennington, Wings, Women and War: Soviet Airwomen in World War II Combat (Lawrence, KS: University Press of Kansas, 2001), 155 and Barbara Alpern Engel, "The Womanly Face of War," in Women and War in the Twentieth Century: Enlisted With or Without Consent, ed. Nicole Ann FOLKLORICA 2013, Vol. XVII 
Dombrowski (New York and London: Garland Publishing, Inc., 1999), 149. For a thorough discussion of pro-natalist policies, see Mie Nakachi's chapter "Population, politics and reproduction: Late Stalinism and its legacy” in Late Stalinist Russia: Society between reconstruction and reinvention, ed. Juliane Furst (London and New York: Routledge, 2006), 23-45.

15 Veteran Galina Markova, a pilot, titled her 1971 memoir Iunost' $v$ ogne [Youth on Fire], an allusion to Drunina's famous “Kachaets'ia rozh' neszhataia” ["The Unharvested Rye Sways”]. See Galina Markova (1971). She chose the poem as her epigraph for that book and her 1983 Rasskazhi bereza...dokumental'nye povesti. Ekaterina Polunina, another pilot, commences her memoirs Devchonki, podruzhki, letchitsy with Drunina's “ $v$ semnadtsat' sovsem uzhe byli my vzroslye ved' nam podrastat' na voine dovelos" ["At 17, we were already grown as you know it happened that we grew up during the war”] [Polunina 2004, 3].

16 The byliny include numerous examples of women assuming male identities to don armor and wage war on the battlefield.

17 Ryan argues that the female ved'ma rather than the male koldun whose image was most influenced by western witch hysteria in the modern period. He posits that greater contact with westernized Belorussians and Ukrainians turned the Russian concept of witchcraft in a new direction [Ryan 1999, 81].

18 Evgeniia Andreevna Zhigulenko served as a zveno [smallest aviation unit] commander for the $46^{\text {th }}$ guards regiment. At the age of 54, she entered the State Institute of Cinematography at the age of 54 and began making the film about the regiment upon her graduation. [Alexyevich 188, 155]

\section{BIBLIOGRAPHY}

Alexiyevich, S. 1988. War's Unwomanly Face. Keith Hammond and Lyudmila Lezhneva,

trans. Moscow: Progress Publishers. 
Aronova, R. E. 1969. Аронова, Р. Е. Ночные ведьмы [Night Witches]. Москва: Советская Россия.

Bailey, James and Tatyana Ivanova. 1998. An Anthology of Russian Folk Epics. Armonk, New York: M. E. Sharpe.

Bakhtin, M. M. 1981. "Epic and Novel," in The Dialogic Imagination. Austin: The University of Texas Press.

Barker, Adele Marie. 1986. The Mother Syndrome in the Russian Folk Imagination. Columbus, Ohio: Slavica Publishers.

Benstock, Shari. 1997. "Authorizing the Autobiographical” in Feminisms: An Anthology of Literary Theory and Criticism. Robyn R. Warhol and Diane Price Herndl, eds. New Brunswick, NJ: Rutgers University Press, 1138-1154.

Brauner, Sigrid. 1995. Fearless Wives and Frightened Shrews: The Construction of the Witch in Early Modern Germany. Amhearst: University of Massachusetts Press.

Brewer, Marilynn B. and Wendi Gardner. 1996. "Who is this 'We?' Levels of Collective Identity and Self Representations," Journal of Personality and Social Psychology 71 (1): 83-93.

Cassirer, Ernst. 1966. Mythical Thought. New Haven and London: Yale University Press.

Chechneva, M. 1968а. Чечнева, М. Самолеть уходят в ночь [Airplanes leave into the night]. Москва: Военное издательство министерства обороны СОЮЗА ССР.

Chechneva, M. 1968b. Чечнева, М. Летали девчата в гвардейском... [Girls Flew in a Guards Regiment] Чувашское книжное издательство Чебоксары.

Chechneva, М. 1984. Чечнева, М. “Ласточки” над фронтом [Sparrows over the Front]. Москва: Издательство ДОСААФ СССР.

Constantinides, Elizabeth. 1983. "The Female Warrior in Greek Folk Songs,” Journal of Modern Greek Studies 1 (1): 6372.

Conze, Susanne and Beate Fieseler. 2000. Soviet Women as Comrades-in-Arms: A Blind Spot in the History of the War, ed. Robert W. Thurston and Bernd Bonwetsch. Urbana, Illinois: University of Illinois Press, 209-234. 
Drunina, Iuliia. 1989. Друнина, Юлия. Избранное в двух mомах [Selected Works in Two Volumes]. Москва: Художественная литература.

Engel, Barbara Alpern, "The Womanly Face of War," in Women and War in the Twentieth Century: Enlisted With or Without Consent, ed. Nicole Ann Dombrowski. New York and London: Garland Publishing, Inc., 1999.

Gil'ferding, А. F. 1938. Гильфердинг, А. Ф. Онежские былины [Onezhskie Epic Poetry]. Vol 2. Москва и Ленинград: Издательство Академии Наук СССР.

Hubbs, Joanna. 1993. Mother Russia: The Feminine Myth in Russian Culture. Bloomington: Indiana University.

Ivanits, Linda. 1989. Russian Folk Belief. Armonk, NY: M.E. Sharpe.

Ivanova-Kazas, О. М. 2006. Иванова-Казас, О. М. Птицы в мифологии, фольклоре и искусстве [Birds in Mythology, Folklore and Art]. Санкт-Петербург: Нестор История.

Jung, Carl. 1964. Man and His Symbols. Garden City, NY: Doubleday and Company.

Kaberov, Igor. 1999. Swastika in the Gunsight: Memoirs of a Russian Fighter Pilot 1941-45. Peter Rule, trans. Gloucestershire, UK: Sutton Publishing.

Kirschenbaum, Lisa. 2000. "Gender, Memory, and National Myths: Ol'ga Berggol'ts and the Siege of Leningrad," Nationalities Papers 28 (3): 551-564.

Kalinin, M. I. 1953. On Communist Education; selected speeches and writings. Moscow: Foreign Language Publishing House.

Klaniczay, Gábor and Éva Pócs, (eds.). 2008. Witchcraft Mythologies and Persecutions. Budapest: Central European University Press.

Kononenko, Natalie. 1994. "Women as Performers of Oral Literature: A Re-examination of Epic and Lament," in Women Writers in Russian Literature. Toby W. Clyman and Diana Greene, eds. Westport, Connecticut and London: Greenwood Press, 17-33. 
Krylova, Anna. 2010a. Soviet Women in Combat: A History of Violence on the Eastern Front. Cambridge: Cambridge University Press.

Krylova, Anna. 2010b. "Neither Erased nor Remembered: Soviet Women Combatants and Cultural Strategies of Forgetting in Soviet Russia.” Frank Biess and Robert G. Moeller, eds. Histories of the Aftermath: The Legacies of the Second World War in Europe. Oxford: Berghahn Books, 83-101.

Leonov, L. M. (ed.). 1988. Леонов, Л, М. ред. Библиотека русского фольклора: Сказки книга 1 [The Library of Russian Folklore: Tales Book I]. Москва: Советская Россия.

Likhachev, D. S. 1967. Лихачев, Д. С. Поэтика древнерусской литературы. Ленинград: Наука.

Miller, Frank J. 1990. Folklore for Stalin: Russian Folklore and Pseudofolklore of the Stalin Era. Armonk, New York: M. E. Sharpe.

Nakachi, Mie. "Population, politics and reproduction: Late Stalinism and its legacy.” Juliane Furst, ed. Late Stalinist

Russia: Society between reconstruction and reinvention. London and New York: Routledge, 2006, 23-45.

Noggle, Anne. 1994. A Dance with Death: Soviet Airwomen in World War II. College Station, Texas: Texas A\&M.

Olson, Laura J. 2004. Performing Russia: Folk revival and Russian identity. New York: RoutledgeCurzon.

Pennington, Reina. 1996. "'Do Not Speak of the Serves You Rendered': Women Veterans of Aviation in the Soviet Union,” Journal of Slavic Military Studies 9 (1): 120-151.

Pennington, Reina. 2000. Wings, Women, \& War: Soviet Airwomen in World War II Combat. Lawrence, KS: University Press of Kansas.

Preminger, Alex and T. V. F. Brogan, (eds.). 1993. The New Princeton Encyclopedia of Poetry and Poetics. New York: MJF Books.

Rakobol'skaia, I. and N. Kravtsova. 2002. Ракобольская, И. и Н. Кравцова. Нас называли ночныли ведьмами: Как воевал женский 46-й гвардейский полк ночных 
бомбардировщиков [They called us Night Witches: How the Woman's $46^{\text {th }}$ Guards Regiment of Night Bombers Fought]. Москва: Издательство МГУ.

Ryan, W. F. 1999. The Bathhouse at Midnight: An Historical Survey of Magic and Divination in Russia. Thrupp: Sutton Publishing.

Stone, David R. 2000. Hammer and Rifle: The Militarization of the Soviet Union, 1926-1933. Lawrence, KS: University of Kansas.

Seidmamedova, Zuleika. 1969. Сеидмамедова, Зулейка. Записки летчицьь [A Female Pilot's Notes]. Баку: Гянджлик.

Showalter, Elaine. 1992. Sexual Anarchy: Gender and Culture at the Fin de Siècle. London: Virago.

Snopkov, P. A., A. E. Snopkov, and A. F. Shkliaruk. 2005. Plakaty voiny i pobedy. 1941-1945. Moskva: KontaktKul'tura.

Tumarkin, Nina. 1994. The Living and the Dead: The Rise and Fall of the Cult of World War II in Russia. New York: BasicBooks.

Volkov, Iakov. 1972. “Всегда в строю” ["Forever in the Ranks"], in След на земле великой [A Trace on the Great Earth]. Волков, Яков. Тула: Приобское книжное издательство.

Warner, Elizabeth. 2002. Russian Myths. Austin: University of Texas Press.

Zhigulenko, Evgeniia Andreevna, director. 1981. Евгения Андреевна Жигуленко. В небе ночные ведьмы. Москва: Киностудия имени M. Гор. 